\title{
ANTIOXIDANT ACTIVITY OF DRIED STRAWBERRY JUICES (Fragaria vesca L.) EMULGEL PREPARATION USING CANDLENUT OIL AND IT'S DIFFUSION
}

\author{
Agitya Resti Erwiyani ${ }^{1 *}$, Suwaldi Martodihardjo ${ }^{2}$, and Endang Lukitaningsih ${ }^{2}$
}

\author{
1Faculty of Pharmacy, Ngudi \\ Waluyo University, \\ Jl. Gedongsongo, Candirejo, \\ Ungaran, Semarang, Jawa \\ Tengah, 50513 \\ 2Faculty of Pharmacy, \\ Universitas Gadjah Mada. \\ Skip Utara 55281 Yogyakarta
}

Submitted: $11-04-2016$

Revised: $12-06-2016$

Accepted: $13-08-2016$

${ }^{*}$ Corresponding author

Agitya Resti Erwiyani

Email:

agityaresti@gmail.com
Strawberry (Fragaria vesca L.) is a fruit that contains nutrients with many benefits and used as an antioxidant because of its compounds such as phenolic, ascorbic acid, pelargonidin-3glucoside, cyanidin-3-glucoside and flavonoids. The stability of phenolic compounds in dried strawberry juice can be improved by double emulsion. Primary emulsion dispersed in a gel base (emulgel) expected to produce more stable and better preparation with the ability to release the active ingredient topically. The production of double emulsion preparation ( $A / M / A)$ using candlenut oil as the oil phase with high level of total flavonoid and total anthocyanins of formula were $22.86 \%$ and $55.92 \%$, respectively. The total flavonoid in dried strawberry juice emulgel was able to pass the membrane shed snake skin with higher flux value than that of total flavonoid in the form of emulsion type $A / M$.

Key words: formulation, emulgel, strawberry juice, difussion, shed snake skin

\section{INTRODUCTION}

One of the fruit containing antioxidant substances is strawberry (Fragaria vesca L.). Strawberries contain phenolic, ascorbic acid (71.2 $\pm 4.9 \mathrm{mg} / 100 \mathrm{~g})$, pelargonidin-3-glucoside

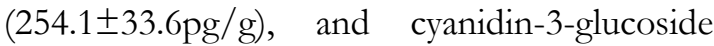
(9.8土1.8ug/g) (Crecente-Campo et al., 2012). High content of ascorbic acid, phenolic, flavonoid and anthocyanin plays important role for the antioxidant activity (Shin et al., 2007; Mosquera et al., 2012).

Strawberries also contain coenzyme Q10 of $1.4 \mathrm{ug} / \mathrm{g}$ of wet weight showing antioxidant activity. It can improve skin health, skin repair and improve skin regeneration (Borekova et al., 2008). The ethanol extract of red strawberry fruit in Sweet Charlie varieties and Camarosa showed the EC50 value $(\mathrm{mg} / \mathrm{mL})$ were $58.05 \pm 2.48$ and $39.01 \pm 4.92$, respectively, while for the acetic acid extract were $0.2 \%, 9.71 \pm 4.96$ and 29.86 \pm 5.80 , respectively (Mandave et al., 2014). Strawberries can be used as an antioxidant due to anthocyanins dye, namely pelargonidin 3-O-glucoside and cyanidin3-Oglucoside which dissolved in water (Wang et al., 2014). In addition, flavonoid in strawberries that has high antioxidant capacity (Jin et al.,
2011). Strawberries also have an effect as an anti-melanogenesis, preventing pigmentation of the skin by reducing the tyrosinase activity and melanin content in the melanocytes resulting in brightening the skin (Zhu et al., 2015).

The use of a combination of hydrophilic and lipophilic surfactants lead to stability of double emulsion (Akhtar et al., 2010). The primary emulsion is dispersed in Carbopol, a gelling agent that can be used in stabilizing the emulsions by lowering the surface tension and increases the viscosity of the water phase (Khullar et al., 2012). Candlenut oil is used as the oil phase because of its high oleic acid as enhancers. Oleic acid able to increase the permeability of the skin by influencing the composition of the stratum corneum which is hydrophobic so that it can increase the penetration (Kogan and Garti, 2006).

Use of strawberries in the form emulgel obtains more benefits, efficient and practical. In addition, making the emulgel preparation is expected improving the stability then its ability to release the active ingredient topically become better. From this research, the release of the active ingredient was tested using the transport test through membranes shed snake skin. This 
method was chosen because it has stratum corneum content similar to human, and it is also expected to describe the release of emulgel strawberries preparation when it is used topically (Itoh et al., 1990).

The purpose of this study is to make preparation to improve the stability of the antioxidant content in dried strawberry juice.

\section{MATERIALS AND METHODS Research Materials}

Strawberries (Fragaria vesca L.) are from Banyuroto village, hazelnut oil, tween 80 (Bratachem), span 80 (Bratachem), propylene glycol (Bratachem), Croduret 50ss (Croda), Carbopol (Bratachem), PEG 400 (Bratachem ), $\mathrm{HCl}$ (Sigma-Aldrich), ethanol (Sigma-Aldrich), raw quercetin, aquabidest (Bratachem), $\mathrm{CH} 3 \mathrm{COONa}, \mathrm{KCl}, \mathrm{AlCl}$, no.1 Whatmann paper, filter paper, PBS buffer solution $\mathrm{pH}$ 7.4; citrate buffer $\mathrm{pH}$ 5.4; membrane shed snake skin.

\section{The determination of the antioxidant activity of dried strawberry juice}

Lost of drying content was measured using moisture balance equipment at $105^{\circ} \mathrm{C}$. Dried strawberry fruit juice was carefully weighed in $500 \mathrm{mg}$ and $125.7 \mathrm{mg}$ of raw quercetin dissolved with $96 \%$ ethanol p.a in $50 \mathrm{~mL}$ flask. This solution was pipetted and diluted. Each solution was added with $0.4 \mathrm{mM}$ DPPH and $96 \%$ ethanol p.a until it reached mark boundaries. The mixture was then shaked until became homogeneous mixture for $30 \mathrm{~min}$. The absorbance of this solution was measured at $517 \mathrm{~nm}$ wavelength. Then, the absorbance of reading negative control and a positive control was determined by using quercetin.

\section{Determination of the percentage of flavonoid and anthocyanin of strawberry fruit juice}

Level of flavonoid: dried strawberry juice was weighed and diluted with 96\% ethanol in a flask and filtering. Absorbance of the solution was measured at maximum wavelength.

The determination of total anthocyanins level: dried strawberry juice was reconstituted using $0.1 \% \mathrm{HCl}$ ethanol $96 \%$ (8.5 to $1.5 \mathrm{~mL}$ ). Each $1 \mathrm{~mL}$ solution was taken and put in a
$50 \mathrm{~mL}$ flask separately. Each solution was diluted using buffer solution $\mathrm{pH} 1$ and $\mathrm{pH} 4.5$. and the absorbance of each solution is measured at a wavelength of $700 \mathrm{~nm}$. The result of absorbance was then calculated using the formula (Lee et al., 2005 and Tonutare et al., 2014):

$\mathrm{A}=\left(\mathrm{A} \lambda_{\text {maks }}-\mathrm{A} \lambda_{700 \mathrm{~nm}}\right) \mathrm{pH} 1-\left(\mathrm{A} \lambda_{\text {maks }}-\lambda_{700 \mathrm{~nm}}\right) \mathrm{pH} 4.5$

The total anthocyanin was calculated using the following formula:

TotalAnthocyanins $\left(\frac{\mathrm{mg}}{\mathrm{L}}\right)=\left(\frac{\mathrm{A} \times \mathrm{MW} \times \mathrm{DF} \times 100}{\varepsilon \times \mathrm{I}}\right)$

Where $\boldsymbol{\varepsilon}$ is $36000 \mathrm{~L} / \mathrm{mol}$, MW is the molucular weight, I is the cuvette optical pathlength $(1 \mathrm{~cm})$ andDFis the dilution factor.

The formulation formula of emulsion preparation type A / $M$ and emulgel (double emulsion) of dried strawberry juice

Emulsion preparation was made using three emulsifier components, i.e., span 80, croduret 50ss, and propylene glycol. Dried strawberry juice was dissolved with $\mathrm{HCl} 0.1 \%$ PEG 400 (3:1) with $\mathrm{pH} 3$ and it was used as water phase. The water phase mixed with propylene glycol. Then, the oil phase was made by mixing the candlenut oil with span 80 and croduret 50ss. The water phase was poured carefully in the oil phase and it was stirred by at $1500 \mathrm{rpm}$ for $20 \mathrm{~min}$ (emulsion type $\mathrm{A} / \mathrm{M}$ ). Carbopol was dispersed in water and stirrer with 750rpm. TEA and tween 80 were added into gel. Emulsion type A/M was added into gel phase and stirred with at 500rpm until became emulgel (double emulsion).

\section{Determination of the percentage of flavonoid and anthocyanins emulgel formula}

The determination of flavonoid: $1 \mathrm{~g}$ of emulgel was dissolved in $96 \%$ of ethanol (stock solution). One $\mathrm{mL}$ of stock solution was diluted with $96 \%$ of ethanol up to $50 \mathrm{~mL}$. The absorbance was read at maximum wavelength. The lowerlevel of flavonoid was calculated by using the linear regression equation of quercetin standard curve.

Determination of total anthocyanins level: one gram of emulgel was carefully weighed and dissolved in $10 \mathrm{~mL}$ using $\mathrm{HCl} 0.1 \%$ : 


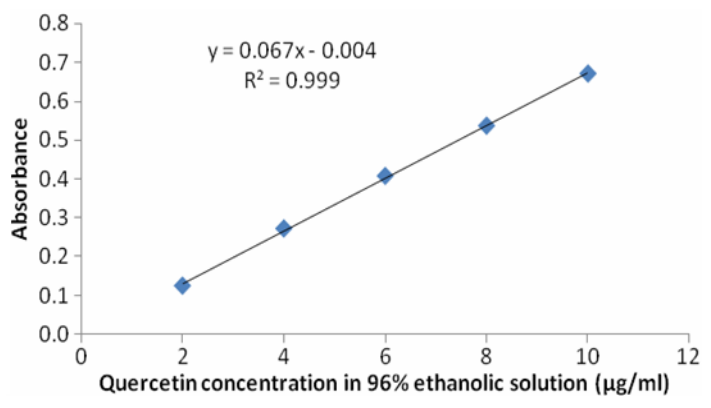

Figure 1. The calibration curve of standard solution of quercetin in $96 \%$ ethanol at 2$10 \mathrm{ug} / \mathrm{mL}$ concentration

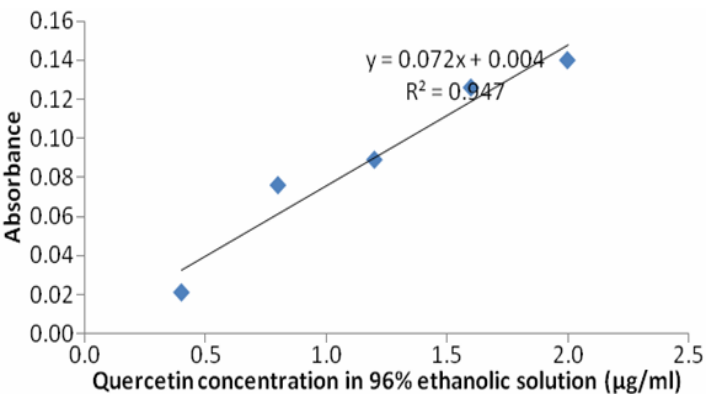

Figure 2. The calibration curve standard solution of quercetin in $96 \%$ ethanol at $0.4-2$ $\mathrm{ug} / \mathrm{mL}$ concentration

Table I. The percentage of inhibition of radical DPPH from various series concentration of dried strawberry juice

\begin{tabular}{cc}
\hline Dried Strawberries Juice Concentration $\mathbf{~} \mathbf{m g} / \mathbf{~ m L})$ & \% Inhibition of radical DPPH \\
\hline 80 & 24,682 \\
160 & 27,070 \\
240 & 48,567 \\
480 & 63,694 \\
640 & 77,866 \\
\hline
\end{tabular}

etanol 96\% (8.5: 1.5). Each solution was taken $1.0 \mathrm{~mL}$ and added to the $\mathrm{pH} 1.0$ solution of $0.025 \mathrm{M} \mathrm{KCl}$ solution and $\mathrm{pH} 4.5$ of $0.4 \mathrm{M}$ acetate buffer. The absorbance was measured at a wavelength of $496 \mathrm{~nm}$ and $700 \mathrm{~nm}$. The total anthocyanin level was calculated using the equation.

\section{The membrane transport test through shed snake skin}

The membrane transport test in this study was done by using Franz diffusion cell, which has $1.4 \mathrm{~cm} 2$ area of diffusion capacity, $1.0 \mathrm{~g}$ donor compartment and the receptor compartment volume $26.0 \mathrm{~mL}$. The receptor compartment filled with saline phosphate buffer with $\mathrm{pH} 7.4$ and stirred using a magnetic stirrer 100rpm, then used a shed snake skin with buffer cellophane coated membrane. The transport test is done by taking a sample of $2.0 \mathrm{~mL}$ of the receptor compartment using a syringe and replaced with a solution of phosphate buffer at $\mathrm{pH} 7.4$ for $8 \mathrm{~h}$. The sample of solution was taken and its absorbance was measured with UV-VIS spectrophotometry at maximum wavelength of 377nm (Ibrahim et al., 2007; Khullar et al., 2012; and Kuramoto et al., 1996).

\section{RESULT AND DISCUSSION \\ Determination of antioxidant activity of dried strawberry juice}

The determination of flavonoid was done quantitatively using UV-Vis spectrophotometry (Figure 1 and 2). The preparation of standard curve was done by dissolving the quercetin in ethanol $96 \%$ at a wavelength of $377 \mathrm{~nm}$. Quercetin in alcohol has a maximum wave-length at 258 and $375 \mathrm{~nm}$ (Budavari, 1996).

The equation of the compound quercetin standard calibration curve was used quantitatively to analyse the total flavonoid content in dried strawberry juice. The result of antioxidant activity of strawberry fruit, as follows: the regression equation $\mathrm{y}=0.096 \mathrm{x}+$ $17.54\left(\mathrm{R}^{2}=0.953\right)$ with $\mathrm{IC}_{50}$ values of dried strawberry juice was $0.338 \mathrm{mg} / \mathrm{mL}$.

The regression equation was $\mathrm{y}=27.67 \mathrm{x}$ $31.07 \quad\left(\mathrm{R}^{2}=0.995\right)$ obtained with the raw quercetin test. The $\mathrm{IC}_{50}$ value of quercetin from the result of research was $2.93 \mathrm{ug} / \mathrm{mL}$. From the research, comparison of $\mathrm{IC}_{50}$ between dried strawberry juice against antioxidant activity of quercetin suggested that dried strawberry juice $1 / 115$ times weaker than the antioxidant activity of quercetin (Table I) 
because quercetin is a pure compound therefore having greater activity.

\section{Determination of flavonoid and anthocyanin of strawberry fruit juice}

The concentration of quercetin in $96 \%$ ethanol was represented in the equation $\mathrm{y}=0.067 \mathrm{x}-0.004$ with a correlation coefficient $\left(\mathrm{R}^{2}=0.9997\right)$. The test result of flavonoid in dried strawberry juice was $22.86 \%$ w/w, meaning there were $228.6 \mathrm{mg}$ of flavonoid presence in $1 \mathrm{~g}$ of dried strawberry juice.

The content of anthocyanin in strawberries with various conditions of $\mathrm{pH}$ and absorbance was measured at a wavelength of $496 \mathrm{~nm}$ and $700 \mathrm{~nm}$ in the solution for $\mathrm{pH} 1.0$ using $0.025 \mathrm{M} \mathrm{KCl}$ buffer solution and acetate buffer $\mathrm{pH} 4.5$ which was used as a blank $0.4 \mathrm{~m}$ in calculating the total of anthocyanin content. The results showed that the anthocyanin content was $55.915 \%$ or $559.15 \mathrm{mg} / 1 \mathrm{~g}$ of dried strawberry juice.

\section{Preparation process of emulsion formula type A / $M$ and emulgel (double emulsion) of strawberry fruit juice}

The preparation of dried strawberry juice formula emulgel was done in several stages with the determination of the primary emulsion base and materials as the first stage. Further primary emulsion formed was dispersed into the gel base.

Preparation of primary emulsion changed when it was stored for 14 days in organoleptis, such as change in color, $\mathrm{pH}$ and viscosity of emulgel preparation. This change occurred due to the degradation of anthocyanins and quercetin.

Organoleptic assessment of emulgel preparation

Organoleptic evaluation was done toward the emulgel to see the characteristics of emulgel. The evaluation of characteristics of the primary emulsion and emulgel included the color preparation which produce, odor, and homogeneity. The color of primary emulsion preparation changed during 14 days of storage. Firstly, the original pink looked the same to homogeneous solution, visually interesting and no precipitate formed then the color changed into pale pink. From its smell and stickiness parameters when it was smeared on the skin surface showed that the typical smell of hazelnut oil with high concentration of span 80 gave the impression of stickiness on the skin surface. From the homogeneity parameter indicated that the preparation was homogeneous primary emulsion (Table II).

The fading of pink color in the preparation of primary emulsion might be caused by reduction of anthocyanin level. Anthocyanin is red pigment, which is presence in the strawberries. The anthocyanin level in improper storage condition might reduces due to the increase in temperature (Wang et al., 2014)

The measurement of $\mathrm{pH}$

The results of $\mathrm{pH}$ measurement in primary emulsion of dried strawberry juice in storage with temperature of $4^{\circ} \mathrm{C}, 25^{\circ} \mathrm{C}$ and $45^{\circ} \mathrm{C}$ for 28 days increased the $\mathrm{pH}$. This primary emulsion experienced a significant rise in $\mathrm{pH}$ statistically using single sample t-test ( $\mathrm{p}$ $<0.05)$. The increase in $\mathrm{pH}$ during the storage also occurred in the emulgel preparation along with storage duration in the conditions of $25^{\circ} \mathrm{C}$. The $\mathrm{pH}$ emulgel (double emulsion) of dried strawberry juice increased in the storage condition for 28 days. It may because of the influence of the temperature and the emulsifier content which influenced by $\mathrm{pH}$.

\section{Determination formula of flavonoid and anthocyanin}

The measurement of flavonoid in dried strawberry juice emulgel on first day was $13.89 \%$ and its content decreased in the storage condition for 30 days at $4^{\circ} \mathrm{C}, 25^{\circ} \mathrm{C}$ and $45^{\circ} \mathrm{C}$ with value $2.97 \% ; \quad 5.35 \%$ and $2.08 \%$, respectively. The decrease in flavonoid was due to the influence of temperature. While the results of measurement of anthocyanin content in emulgel on the first day was $7.36 \%$. During storage condition, anthocyanin concentration was $1.84 \%$. There was a decrease in anthocyanin content during the storage as a result of the increase of $\mathrm{pH}$ in preparation step.

\section{Test of transport membrane through shed snake skin}

In the experiment of diffusion through the membrane revealed only small amount of flavonoid pass through, when it was at the form of primary emulsion and emulgel. 
Table II. Physical changes of emulsion stability in storage condition

\begin{tabular}{ccl}
\hline $\begin{array}{c}\text { Period of } \\
\text { Storage (days) }\end{array}$ & $\begin{array}{c}\text { Storage } \\
\text { Temperature }\left({ }^{\circ} \mathbf{C}\right)\end{array}$ & \multicolumn{1}{c}{ Changes Happened } \\
\hline 0 & 25 & No changes in color and form emulsion \\
4 & No change in color and form emulsion \\
7 & 25 & No changes and emulsion form \\
45 & Pale pink color, no changes in the form of an emulsion \\
4 & Pale pink color, not deformed emulsion \\
14 & 25 & Pale pink color, not deformed emulsion \\
& 45 & Pale pink color, cracking occurs \\
\hline
\end{tabular}

Table III. Values of Q cumulative flux and permeability coefficient of total flavonoids through shed snake skin membrane

\begin{tabular}{ccc}
\hline Parameter & Emulgel & Primer Emulsion \\
\hline Q cumulative & $188.298 \mu \mathrm{g}$ & $133.214 \mu \mathrm{g}$ \\
The flux & $0.0032 \mu \mathrm{g} / \mathrm{cm}^{2} / \mathrm{sec}$ & $0.0029 \mu \mathrm{g} / \mathrm{cm}^{2} / \mathrm{sec}$ \\
The permeability coefficient & $8.402 \times 10^{-5} \mathrm{~cm}^{\mathrm{sec}}$ & $7.58 \times 10^{-5} \mathrm{~cm}^{\mathrm{sec}}$ \\
The diffusion coefficient & $2.184 \times 10^{-5} \mathrm{~cm}^{2} / \mathrm{sec}$ & $1.971 \times 10^{-6} \mathrm{~cm}^{2} / \mathrm{sec}$ \\
\hline
\end{tabular}

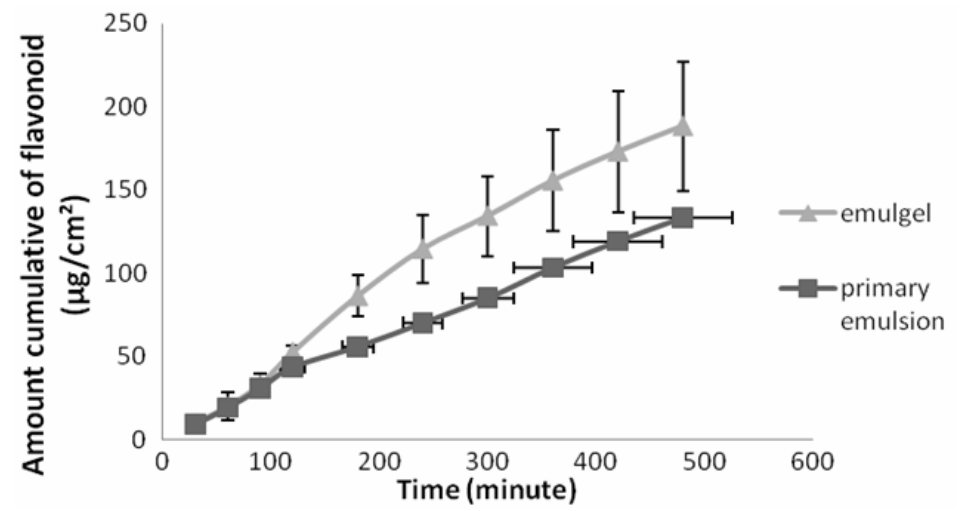

Figure 3. The relationship curve of amount cumulative of flavonoid $(\mathrm{ug} / \mathrm{cm} 2)$ through shed snake skin membrane of emulgel and the primary emulsion of dried strawberry juice.

Diffusion experiment through membrane yielded linear regression equation, $\mathrm{Y}=0.193$ $\mathrm{x}+30.28\left(\mathrm{R}^{2}=0.994\right)$. The same experiment on primary emulsion produced a linear regression equation $\mathrm{Y}=0.174 \mathrm{x}+3.704 \quad\left(\mathrm{R}^{2}=0.996\right)$. The linear regression equation can be used to determine cumulative Q, flux, permeability coefficient and diffusion coefficient of flavonoid (Figure 3).

Drug release was related to the stability of the preparation, in case if the coalescence occurs in the internal phase or the broken of oil droplet affect the release of drug molecules.
In the form of double emulsion preparation, the diffusion ability to pass a greasy thin membrane may occur if an oily layer is not semipermeable, and there is an osmotic gradient factor related to the flow of water molecules (Lieberman, 1998).

The speed of diffusion release on the $\mathrm{A} / \mathrm{M} / \mathrm{A}$ system can be divided into diffusion and rupture of emulsion or membrane rupture. This is influenced by the polarity, molecular weight of the drug and the type or concentration of surfactant. 
Diffusion emulsion $A / M / A$ posses three processes, namely the release of drug molecules and the first droplet, the partition between the oil phase and water phase, and the movement of the drug into membranes. Diffusion ability of the double emulsion related to the lag time needed to complex partition molecules. The drug release is influenced by the concentration of emulsifier if the concentration of lipophilic is high, the globules of oil will expand and the drug release will be delayed. Lipophilic surfactant will diffuse on the surface and give a synergistic effect to increase the strength of the membrane (Dong et al., 2015 and Vasiljevic et al., 2006).

Gel diffusion capability is affected by the size of the pores in the gel, where based-on the literature range between 30 to $40 \mathrm{~nm}$ so that only the effective diffusion may happen. The higher the concentration of the gel, will have the lower the diffusion capability (Quino et al., 2016). The presence of Tween 80 in the preparation of emulgel has function to improve the molecules diffusion. The concentration of non-ionic surfactant can increase the permeation of skin because it has the dispersion ability in intracellular lipid phase on the stratum corneum increasing the fluidity and reducing the diffusion barriers (Ibrahim et al., 2007).

According to Ainurofiq (2006), the drug release of emulsion type $\mathrm{A} / \mathrm{M}$ are more difficult might due to blockage of oily layer so that the barrier layer can not be penetrated by the polar flavonoid, namely non-polar hazelnut oil. In releasing the drug by erosion mechanism, there is the depletion of oily layer or broken emulsion. The double emulsion A/ M/A has a more complicated mechanism through coalescence, diffusion mechanism and permeation. Coalescence causes damage to the thin layer between the liquid phase granules in the granular surface of the outer phase or erosion, while the diffusion mechanism and permeation of chemical substances penetrates the oil phase. The release of flavonoid in the form of double emulsion from the process of breaking up of the oily layer into outer layer subsequently penetrates the membrane.

Emulsion type $\mathrm{A} / \mathrm{M}$ showed the maximum distance when it is transported and influenced by the size and shape of the droplet, causing the delay diffusion in a long period compares to when in the outer aqueous phase. Diffusion of water which passes through the oily layer was lower compare with oil diffusion in the aqueous layer due to the saturation of the water on the oily layer. The water diffusion in water-saturated oily phase is influenced by temperature and water solubility (Vermeir et al., 2016).

\section{CONCLUSION}

The dried strawberry juice (Fragaria vesca L.) has antioxidant activity with $\mathrm{IC}_{50}$ value of $0.338 \mathrm{mg} / \mathrm{mL}$. The production of emulgel dried strawberry juice unable to improve the stability of the antioxidant compound content. Emulgel penetration through the shed snake skin membrane was better than that of the primary emulsion preparation form of type A/M.

\section{ACKNOWLEDGEMENT}

The research team would like to thank to the Graduate Grant of Pharmacy Faculty which has provided funds to our research.

\section{REFERENCE}

Ainurofiq, A., 2006. 'Pengaruh tipe emulsi sederhana dan emulsi ganda terhadap pola pelepasan Natrium Salisilat secara In Vitro', Thesis. Universitas Gadjah Mada, Yogyakarta.

Crecente-Campo J., Nunes-Damaceno, M., Romero-Rodríguez MA., and VázquezOdériz ML., 2012. Color, Anthocyanin Pigment, Ascorbic Acid and Total Phenolic Compound Determination in Organic Versus Conventional Strawberries (Fragaria $\times$ ananassa Duch, cv Selva). J Food Comp and An, 28: 23-30.

Dong L., Liu C., Cun D., and Fang L., 2015. The effect of rheological behavior and microstructure of the emulgels on the release and permeation profiles of Terpinen-4-ol. Eur. J.Pharm.Scie.,78: 140-150.

Ibrahim, E.-S.A., Hassan, M.A., El-Mahdy, M.M., and Mohamed, A.S., 2007. Formulation and evaluation of quercetin in certain dermatological preparations. $J$. DRUG DEL. SCI. TECH, 17: 431-436.

Itoh, T., Xia, J., Magavi, R., Nishihata, T., and Rytting, J.H., 1990. Use of Shed Snake 
Skin as a Model Membrane for in Vitro Percutaneous Penetration Studies: Comparison with Human Skin. Pharm. Rese., 7: 1042-1047.

Jin, P., Wang, S.Y., Wang, C.Y., and Zheng, Y., 2011. Effect of cultural system and storage temperature on antioxidant capacity and phenolic compounds in strawberries. Food Chemistry, 124: 262270.

Khullar, R., Kumar, D., Seth, N., and Saini, S., 2012. Formulation and evaluation of mefenamic acid emulgel for topical delivery. Saudi Pharm. J., 20: 63-67.

Kuramoto, M., Tanaka, T., Makita, H., Nakamura, Y., and Yata, N., 1996. Characteristics of Shed Snake Skin Permeability to Indomethacin and Fatty Alcohols. J. Pharm. Pharmacol., 48: 680684.

Lee, J., Durst, R.W., and Wrolstad, R.E., 2005. Determination of total monomeric anthocyanin pigment content of fruit juices, beverages, natural colorants, and wines by the $\mathrm{pH}$ differential method: collaborative study. J. AOAC Int., 88: 1269-1278.

Lieberman, H. (Editor), 1998. Pharmacentical Dosage Forms: Disperse Systems, Second Edition, Volume 3, 2 edition. Informa Healthcare, New York.

Mandave, P.C., Pawar, P.K., Ranjekar, P.K., Mantri, N., and Kuvalekar, A.A., 2014. Comprehensive evaluation of in vitro antioxidant activity, total phenols and chemical profiles of two commercially important strawberry varieties. Scientia Horticulturae, 172: 124-134.

Mosquera, L.H., Moraga, G., and MartínezNavarrete, N., 2012. Critical water activity and critical water content of freeze-dried strawberry powder as affected by maltodextrin and arabic gum. Food Research International, 47: 201-206.

Quino, J., Ruehl, M., Klima, T., Ruiz, F., Will, S., dan Braeuer, A., 2016. Supercritical drying of aerogel: In situ analysis of concentrationprofiles inside the gel and derivation of the effective binary diffusioncoefficient using Raman spectroscopy. J. Supercri Fluids, 108: 1-12.

Shin, Y., Liu, R.H., Nock, J.F., Holliday, D., dan Watkins, C.B., 2007. Temperature and relative humidity effects on quality, total ascorbic acid, phenolics and flavonoid concentrations, and antioxidant activity of strawberry. Postharv Bio and Tech., 45: 349-357.

Vasiljevic, D., Parojcic, J., Primorac, M., dan Vuleta, G., 2006. An investigation into the characteristics and drug release properties of multiple $\mathrm{W} / \mathrm{O} / \mathrm{W}$ emulsion systems containing low concentration of lipophilic polymeric emulsifier. Int. J.Pharm., 309: 71-77.

Vermeir, L., Sabatino, P., Balcaen, M., Declerck, A., Dewettinck, K., and Martins, J.C., 2016. Effect of molecular exchange on water droplet size analysis in $\mathrm{W} / \mathrm{O}$ emulsions as determined by diffusion NMR. J. Colloid and Interface Science, 463: 128-136.

Wang, Z., Zhang, M., and Wu, Q., 2014. Effects of temperature, $\mathrm{pH}$, and sunlight exposure on the color stability of strawberry juice during processing and storage. LWT-Food Scie. Tech.,60:11741178.

Zhu, Q., Nakagawa, T., Kishikawa, A., Ohnuki, K., and Shimizu, K., 2015. In vitro bioactivities and phytochemical profile of various parts of the strawberry (Fragaria $\times$ ananassa var. Amaou). J.Funct. Foods, 13: 38-49. 